\title{
KAJIAN SOSIO-BIOLOGI MINUMAN BARAM MASYARAKAT DAYAK WILAYAH KATINGAN KALIMANTAN TENGAH
}

\author{
RITA RAHMANIATI ${ }^{1)}$ DAN SUPRAMONO ${ }^{2)}$ \\ 1) Dosen Fakultas Keguruan dan IImu Pendidikan Universitas Muhammadiyah Palangkaraya \\ 2) Dosen Fakultas Keguruan dan IImu Pendidikan Universitas Palangka Raya
}

\begin{abstract}
The purposes of this research are for 1) To describe a perception about "Baram" in Dayak Ethnic in Katingan, Central Kalimantan. 2) To analyze the content of alcohol in "Baram". 3) To analyze the content of microorganism in "Baram". 4) To exam the Organoleptic in "baram" in Dayak Ethnic in Katingan, Central Kalimantan.

The method that used in this research is using survey research method to reveal the data that related with sociology form connected with "Baram". Whereas, the study related with the biology form using laboratory examination that consist of : study of the data about the role of microbiology during the fermention process in treating "Baram". Beside that also examined the study toward the content of alcohol or organoleptic in "Baram".

The result of this research showed that 1) People perception in Dayak Ethnic in Katingan, Central Kalimantan toward "Baram" showed that almost all of the people don't know the content of alcohol in "Baram" so there is a tendency to the people to still use "Baram" as a special drink for spe cial ceremony because they have not enough knowledge about the positive and negative effect from "Baram". 2) The content of alcohol that consist in "Baram" has a high category of 5,6\% ethanol, relatively more high rather than "Tuak" only 4\%: 3) The role of microorganism in baram fermentation process are Saccharomyces cerevisiae and Saccharomyces bayanus serta Aspergillius onzae; 4) Based on the result of Organoleptic examination toward "Baram" in Dayak Ethnic in Katingan, Central Kalimantan we can conclude that the people like "Baram" because it has special teste and smell.
\end{abstract}

Keywords : sociobiology, dayak people and baram

\section{ABSTRAK}

Penelitian ini bertujuan untuk 1) Mendeskripsikan persepsi tentang minuman "Baram" pada masyarakat suku dayak di wilayah Katingan Kal-Teng; 2) Menganalisis kandungan alkohol yang terdapat pada minuman "Baram"; 3) Menganalisis kandungan mikroorganisme yang terdapat pada minuman "Baram"; 4) Menguji organoletik terhadap minuman "Baram" pada masyarakat suku Dayak di wilayah Katingan Kalimantan Tengah.

Metode yang digunakan dalam penelitian ini menggunakan metode penelitian survey untuk mengungkap data-data yang terkait dengan kondisi sosiologi berkaitan dengan minuman 'Baram'. Sedangkan untuk kajian berkenaan kondisi biologi dilakukan pengujian laboratorium yang meliputi kajian data tentang peranan mikrobiologi selama proses fermentasi dalam pengolahan minuman 'Baram'. Kajian dilakukan juga pada kandungan kadar alkohol dan organoleptik minuman 'Baram'.

Hasil penelitian menunjukkan bahwa 1) Persepsi masyarakat suku dayak di wilayah Katingan KalTeng tentang minuman "Baram" menunjukkan sebagian besar masyarakat masih banyak yang belum mengetahui kandungan alkohol pada minuman Baram sehingga terdapat kecenderungan mereka masih selalu menggunakan Baram sebagai minuman pada upacara tertentu karena mereka belum memiliki pemahaman yang baik tentang dmpak positif negatifnya dari minuman Baram 2) Kandungan alkohol yang terdapat pada minuman "Baram" termasuk kategori cukup tinggi yaitu sebesar 5,6\% etanol, relatif lebih tinggi di bandingkan dengan minuman Tuak sebesar $4 \%$; 3) Mikroorganisme yang berperan pada proses fermentasi minuman "Baram" adalah Saccharomyces cerevisiae dan Saccharomyces bayanus serta Aspergillius onzae; 4) Berdasarkan hasil uji organoleptik terhadap minuman "Baram" pada masyarakat suku Dayak di wilayah Katingan Kalimantan Tengah dapat disimpulkan bahwa masyarakat menyukai minuman baram karena rasa dan aromanya khas.

Kata Kunci : sosiobiologi, masyarakat dayak dan baram 


\section{PENDAHULUAN}

Salah satu budaya masyarakat dayak adalah kebiasaan mengkonsumsi minuman 'Baram' Acara minum 'Baram' ini biasanya dilakukan jika ada acara khusus, seperti perayaan pernikahan, perayaan kebahagiaan, upacara ritual keagamaan, seperti Upacara 'Tiwah' (upacara memindahkan tulang belulang keluarga yang telah meninggal), 'Wara' (upacara pemindahan tulang belulang keluarga yang telah meninggal), 'Balian' (upacara atau prosesi pengobatan), 'Mapalas' (upacara membuang sial atau membersihkan diri dari malapetaka). Selain itu acara minum 'Baram' sebagai simbolis terhadap adanya rasa penghormatan terhadap para tamu undangan yang hadir yang disebut juga dengan 'Potong Pantan' (upacara peresmian atau penyambutan tamu kehormatan), serta sebagai tanda adanya hubungan kekerabatan yang erat antara masyarakat.

Tujuan penelitian ini adalah Mendeskripsikan persepsi tentang minuman "Baram" pada masyarakat suku dayak di wilayah Katingan kal-Teng (2) Menganalisis kandungan alkohol yang terdapat pada minuman "Baram (3) Menganalisis kandungan mikroorganisme yang terdapat pada minuman "Baram (4) Menguji organoletik terhadap minuman "Baram" pada masyarakat suku Dayak di wilayah Katingan Kalimantan Tengah.

Baram' adalah salah satu jenis minuman khas tradisional Dayak yang dibuat dari beras ketan yang difermentasikan dengan ragi tape. Minuman 'Baram' ini merupakan hasil sampingan dari proses pembuatan tape, karena produk tape inilah yang utama dimanfaatkan sebagai sajian dan dimakan. "Baram' mengandung alkohol 3-10 persen. Kadar alkohol dapat berubah selama penyimpanan. Kenaikan kadar alkohol terjadi akibat proses fermentasi yang terus berlangsung selama penyimpanan, sedangkan penurunannya karena proses esterifikasi, oksidasi, dan penguapan. Oksidasi alkohol disebabkan suasana aerobik yang terjadi selama waktu penyimpanan, gula pereduksi, gas $\mathrm{CO}_{2}$, dan sedikit asam organik. 'Baram' terbentuk dari reaksi antara zat tepung dengan enzim dan sedikit air, sehingga menghasilkan gula. Kemudian gula yang dihasilkan bereaksi lagi dengan enzim, sehingga menghasilkan alkohol dan gas $\mathrm{CO}_{2}$.

Dayak atau Daya (ejaan lama: Dajak atau nama yang oleh penduduk pesisir pulau Borneo diberi kepada penghuni pedalaman yang mendiami Pulau Kalimantan. Ada 5 suku atau 7 suku asli Kalimantan yaitu Melayu, Dayak, Banjar, Kutai, Paser, Berau dan Tidung Menurut sensus Badan Pusat Statistik Republik Indonesia tahun 2010, suku bangsa yang terdapat di Kalimantan Indonesia dikelompokan menjadi tiga yaitu suku Banjar, suku Dayak Indonesia (268 suku bangsa) dan suku asal Kalimantan lainnya (non Dayak dan non Banjar). Dahulu, budaya masyarakat Dayak adalah Budaya maritim atau bahari. Hampir semua nama sebutan orang Dayak mempunyai arti sebagai sesuatu yang berhubungan dengan "perhuluan" atau sungai, terutama pada namanama rumpun dan nama kekeluargaannya.

Budaya minum Baram bagi para pria yang mengadakan upacara bersama para tamu adalah suatu kewajiban moral, karena ada anggapan bahwa jika tuan rumah tidak ikut minum bersama para tamu, merupakan sesuatu yang tidak etis atau bahkan yang lebih buruk akan dituduh telah memberikan racun pada makanan dan minuman 
yang telah disuguhkan bagi para tamu, sehingga mau tidak mau mereka pasti ikut arak, tidak peduli apakah oaring tersebut sudah terbiasa minum atau tidak. Begitu pula dengan tamu yang hadir. Pada acara metatah dan menek bajang tentu yang diundang juga berasal dari teman-teman orang yang diupacarai yang rata-rata masih berumur 13-15 tahun dimana mereka sebelumnya belum pernah minum arak, namun karena desakan teman-temannya maka mereka biasanya ikut-ikutan dan mulai terbiasa, sehingga secara tidak langsung budaya ini ikut mempengaruhi penyebaran kebiasaan minum-minuman keras.

\section{METODOLOGI}

Penelitian ini dilaksanakan sejak bulan Oktober sampai dengan Desember 2014. Penelitian ini termasuk penelitian deskriptif kualitatif. Adapun metode penelitian yang digunakan adalah survey untuk mengungkap data-data yang terkait dengan kondisi sosiologi berkaitan dengan minuman 'Baram'. Sedangkan untuk kajian berkenaan kondisi biologi dilakukan pengujian laboratorium yang meliputi kajian data tentang peranan mikrobiologi selama proses fermentasi dalam pengolahan minuman 'Baram'. Selain itu juga dilakukan kajian terhadap kandungan kadar alkohol maupun organoleptik terhadap minuman 'Baram'. Instrumen yang digunakan dalam penelitian ini terdiri atas 1) Angket untuk penggalian data tentang persepsi masyarakat terhadap minuman 'Baram' 2) Perangkat instrumen untuk uji laboratorium terhadap minuman 'Baram' 3) Instrumen pengamatan/pengujian organoleptik terhadap minuman 'Baram'. Teknik pengumpulann data 1) dilakukan wawancara menggunakan angket kepada sampel terpilih 2) dilakukan uji laboratorium di laboratorium biologi Universitas Palangkaraya 3) dilakukan uji di laboratorium biologi Universitas Palangkaraya 4) dilakukan uji organoleptik pada masyarakat pengguna minuman 'Baram. Analisis Data menggunakan deskriptif persentase

\section{HASIL DAN PEMBAHASAN}

Hasil temuan pada saat pengambilan data dilapangan terhadap kebiasaan masyarakat Dayak wilayah Katingan tentang minuman Baram pada acara-acara tertentu dapat dipaparkan sebagai beberapa hal.

\section{Persepsi tentang minuman "Baram" pada masyarakat suku dayak di wilayah Katingan kal-Teng}

Berdasarkan hasil wawancara peneliti dengan beberapa masyarakat pengguna minuman Baram dengan menggunakan kuesioner yang meliputi 3 aspek yaitu Karakteristik Responden, Pengetahuan dan Sikap serta Kultur masyarakat suku Dayak di wilayah Katingan, tepatnya di Desa jahanjang dan Baonbango kabupaten Katingan. Selanjutnya hasil wawancara dapat dilihat pada tabel 1

Berdasarkan Tabel 1 karakteristik masyarakat menurut jenjang pendidikan responden masyarakat desa Baun Bango dan Jahanjang menggambarkan bahwa daerah sampel penelitian termasuk masyarakat yang sadar akan pendidikan. Hal ini karena tidak satupun ditemukan responden yang belum mengenyam pendidikan. 
Bila ditinjau jenis pekerjaan utama masyarakat menunjukkan bahwa selain pekerjaan utama, masyarakat yang tinggal di kedua desa tersebut memiliki pekerjaan lain berupa mencari ikan, mencari rotan, penebang pohon illegal, dan sebagian ada yang menjadi karyawan tidak tetap perkebunan sawit yang ada di sekitar kampong tersebut.

Kemudian jika dilihat dari agama yang dianut masyarakat suku Dayak Katingan desa Baun Bango dan Jahanjang menunjukkan bahwa sebagian besar masyarakat beragama Islam 50\%, Kristen $18 \%$, dan Kaharingan $32 \%$. Walupun terdiri dari berbagai penganut agama yang berbeda, namun Susana kerukunan dan kebersamaan pada masyarakat Dayak Ngaju di kedua desa tersebut tampak sangat harmonis dan saling membantu antara satu dengan lainnya.

Berdasarkan Tabel 2 hasil kuesioner wawancara tentang pengetahuan masyarakat suku Dayak Katingan di desa baun bango dan Jahanjang tentang minuman baram memberikan gambaran walupun sebagian masyarakat tahu mengenai dampak negative minuman baram, namun mereka masih tetap mengkonsumsinya. Hal ini dapat terjadi karena masyarakat pengguna minuman baram masih belum memmahami secara baik tentang minuman baram yang mereka selalu konsumsi selama ini.

Sikap masyarakat terhadap minuman beralkohol sebagian besar setuju jika meminumnya dapat berdampak buruk bagi kesehatan dan tidak baik mengkonsumsi secara berlebihan. Akan tetapi ketika ditanyakan sikap mereka untuk tidak mengkonsumsi minuman baram mereka kebanyakan masih merasa keberatan meninggalkannya. Berkenaan dengan sikap sebagian masyarakat suku Dayak Ngaju yang cenderung mempertahankan tradisi meminum baram tersebut karena selama ini dari wawancara terungkap masih belum ada bimbingan atau penyuluhan tentang dampak dan bahaya minuman beralkohol, termasuk baram. Selain itu juga karena sempitnya pengetahuan dan pemahaman mereka tentang baram yang bahan dasarnya air beras dan rempah-rempah yang selama ini diracik sendiri oleh para pengrajin minuman baram yang menurut pemahaman sebagian besar masyarakat tidak mungkin ada kandungan alkoholnya.

Minum-minuman keras beralkohol termasuk baram ini jika dilakukan dari pukul 17.30 sampai 22.00 dan dilakukan sambil megenjekan, tempat mereka minumpun tidak tanggung-tanggung, mulai dari banjar, pos kamling, sampai jalan-jalan sepi mereka duduki dengan santai seolah jalan tersebut milik mereka, hal ini mengganggu ketertiban umum sehingga tidak jarang menimbulkan ketegangan yang berujung pada perkelahian. Perlu pemikiran dan pembinaan lebih serius tentunya agar dapat mengeliminir kerawanan social yang ditimbulkan oleh minuman baram.

Respon masyarakat suku dayak Ngaju Katingan ditinjau dari kultur yang ada ditunjukkan pada Tabel 3. Berdasarkan pada Tabel 3 di desa Baun bango dan Jahanjang wilayah Kabupaten katingan masyarakatnya $100 \%$ berasal dari suku Dayak Ngaju. Menurut hasil survey yag dilakukan tidak semua suku Dayak ngaju menyukai minuman baram. Namun ketika ditanyakan ketika kegiatan upacara adat ada kaitannya dengan kegiatan meminum baram sebagian besar $91 \%$ menyatakan setuju dan hanya sebagian kecil saja 
$4.5 \%$ yag menyatakan tidak. Selanjutnya ketika pertaanyaan diarahkan jika kegitan meminum minuan baram ditiadakan ketika upacara-upacara adat ditiadakan mereka keberatan. Alasan keberaatannya menurut masyarakat karena kegiatan meminum baram itu merupakan salah satu ritual, maka jika dihilangkan bisa menimbulkan bencana yang tiba-tiba misalnya banyak warga yang sakit, banjir besar, atau mitosmitos lainnya. Oleh karena itu menurut sebagian besar masyarakat upacara ritual minum baram merupakan hal yang harus tetap ada.

Kemudian ketika pertanyaan diarahkan pada masyarkat jika dalam upacara adat minuman baram digantikan dengan jenis minuman lain yang tidak memabukkan sebagian masyarakat setuju $59 \%$, sedangkan sebagian dari mereka tidak setuju. Ketidaksetujuan mereka ini dengan alas an bahwa upacara meminum baram ini merupakan tinggalan nenek moyang mereka. Oleh karenanya jika dirubah akan dapat malapetaka di kampong tersebut. Selanjutnya setelah digali lebih mendalam lagi sebagan ada yang berpendapat jika kegitan meminum baram ini harus digantikan minumannya dengan jenis minuman lainnya, maka harus tetap ada juga disertakan minuman baram untuk menghindari kemarahan leluhur, tutur mereka.

\section{2). Analisis kandungan alkohol dan organoleptik yang terdapat pada minuman "Baram" berdasarkan uji laboratorium}

Berdasarkan hasil pengujian laboratorium terhadap minuman Baram dapat dilihat pada tabel 4. Berdasarkan hasil pengujian di laboratorium BPOM Palangkaraya terhadap minuman baram menunjukkan hasil bahwa secara organoleptik baram berbentuk cair, berwarna agak keruh, warna kekuningan, mmiliki bau khas dan rasa yang khas juga. Sementara itu hasil uji kandungan alcohol menunjukkan hasil bahwa minuman baram memiliki kandungan alkohol sebanyak 5,6\%. Hasil ini memberikan gambaran bahwa minuman baram termasuk jenis minuman yang membahayakan kesehatan jika dikonsumsi.

Jika kandungan alkohol darah melebihi 5 persen, si petninum akan merasa tidak enak dan secara bertahap akan kehilangan kendali bicara, keseimbangan, dan emosi. Tak heran, pelaku pemerasan sering mendatangi korban dalam keadaan setengah mabuk. Dalam kondisi tersebut, si pelaku menjadi lebih berani gara-gara sudah kehilangan emosi. Jika kandungan alkohol dalam darah dinaikkan sebesar 0,1 persen, si peminum akan mabuk total. Jika dinaikkan lagi sebesar 0,2 persan, beberapa orang akan menjadi pingsan. Jika kenaikan mencapai 0,3 persen, sebagian orang akan mengalami koma, dan bila 0,4 persen, si peminum kemungkinan besar akan tewas.

\section{3). Kandungan mikroorganisme yang terdapat pada minuman "Baram"}

Setelah dilakukan pengamatan di bawah mikroskop terhadap sampel minuman Baram, beberapa organism yang ditemukan turut berperan dalam proses fermentasi minuman baram dapat dilihat pada tabel 5

Berdasarkan hasil pengamatan dibawah mikroskop terhadap kandungan mikroorganisme yang ada pada minuman baram yang baru sekitar 1-2 minggu difermentasikan ternyata terdapat tiga jenis mikroorganisme, yaitu saccharomyces 
cerevisae, saccharomyces bayanus, dan Aspergillus orizae. Semakin lama proses fermentasi minuman baram akan semakin menghasilkan kandungan alcohol/etanol yang semakin tinggi, sehingga pada akhirnya mikroorganisme akan tidak mampu bertahan hidup lagi.

\section{4) Uji organoletik terhadap minuman "Baram" pada masyarakat suku Dayak di wilayah Katingan Kalimantan Tengah.}

Uji organoleptik minuman Baram dilakukan pada beberapa panelis yang dipilih berdasarkan umur pengguna. Adapun data hasil uji organoleptik yag dilakukan diperoleh data sebagaimana ditampilkan pada Tabel 6 .

Berdasarkan data hasil uji pada Tabel 6 menunjukkan bahwa yang menyatakan warna kekuning-kuningan sebanyak $8 \%$, bening $20 \%$, dan coklat $0 \%$. Berkenaan dengan aroma yang menyatakan tidak menyengat $30 \%$, kurang menyengat $70 \%$, dan tidak menyengat $0 \%$. Adapun rasa menurut responden yang menyatakan pahit $40 \%$, manis $60 \%$, dan tawar $0 \%$. Selanjutnya berdasarkan tingkat kekeruhanya yang menyatakan cukup keruh $70 \%$, keruh $0 \%$, dan tidak keruh $30 \%$.

Berdasarkan hasil, pada dasarnya mereka menyukai minuman baram karena factor kebiasaan dalam pergaulan agar lebih akrab. Mereka juga menyatakan mengkonsumsi minuman baram bukan tujuan untuk mabuk, karena menurut mereka jika mengkonsumsi minuman baram hingga mabuk sangat tidak enak. Bahkan menurut penuturan panelis lainnya ketika baram dikonsumsi belum mengalami fermentasi sempurna yaitu fermentasi 1-2 minggu akan sangat menyiksa diri mereka. Hal ini karena menurut mereka proses mabuknya semakin lama bisa 2 hari baru terasa sembuh, berbeda dengan minuman baram yang sudah berumur lama 6 bulan. Ditambahkan pula jika fermentasinya lama selain mabuknya cepat sembuh juga rasanya lebih enak dan menghangatkan badan. 
Tabel 1. Persentase karakteristik Responden

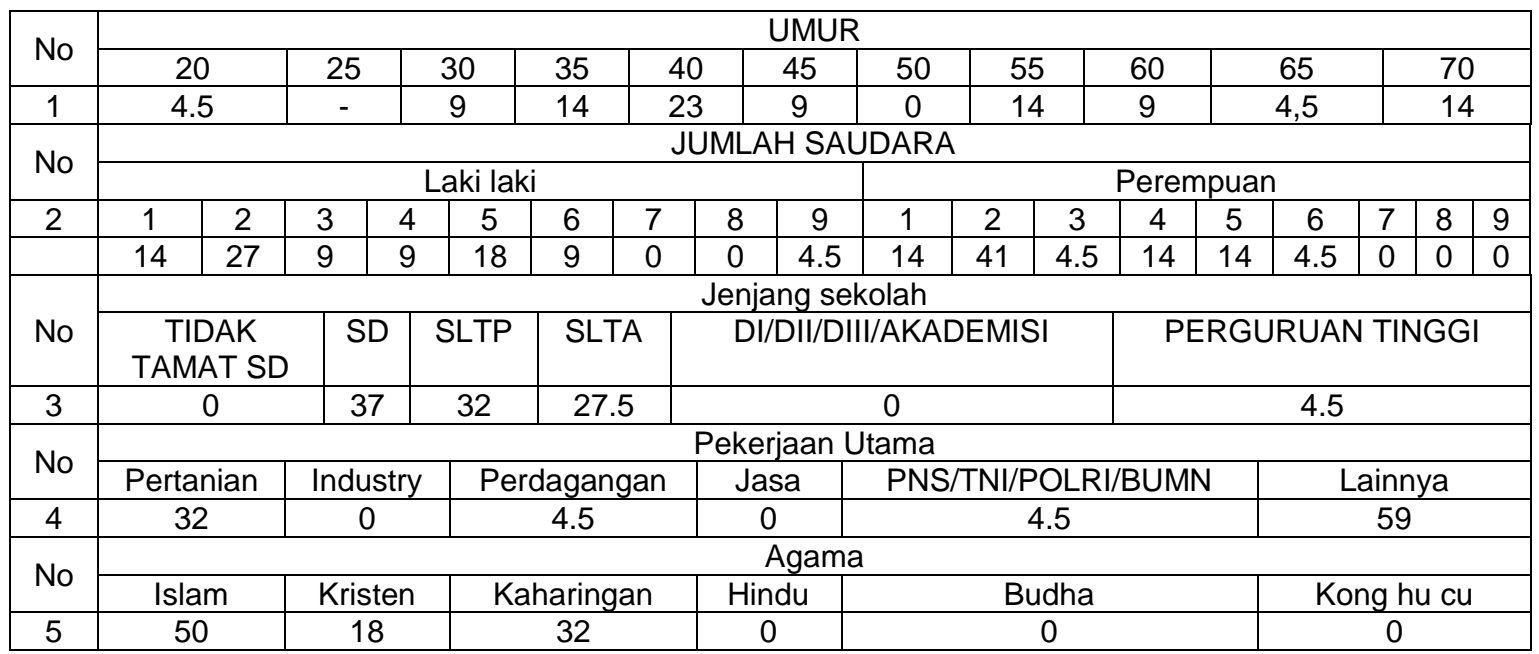

Tabel 2. Persentase pengetahuan dan Sikap responden terhadap minuman Baram

\begin{tabular}{|c|c|c|}
\hline No & \multicolumn{2}{|c|}{ Pengetahuan, sikap terhadap kandungan minuman Baram } \\
\hline \multirow[t]{3}{*}{1} & \multicolumn{2}{|l|}{ Baram mengandung Alkohol } \\
\hline & $\mathrm{Ya}$ & Tidak \\
\hline & 64 & 36 \\
\hline \multirow[t]{3}{*}{2} & \multicolumn{2}{|c|}{$\begin{array}{l}\text { Apakah anda tau bahwa minuman yang mengandung alkohol dapat menimbulkan hilang } \\
\text { kesadaran? }\end{array}$} \\
\hline & $\mathrm{Ya}$ & Tidak \\
\hline & 91 & 9 \\
\hline \multirow[t]{3}{*}{3} & \multicolumn{2}{|c|}{ Apakah kandungan alkohol pada minuman Baram cukup tinggi ? } \\
\hline & Ya & Tidak \\
\hline & 41 & 59 \\
\hline \multirow[t]{3}{*}{4} & \multicolumn{2}{|c|}{ Menurut anda, apakah budaya minum baram memiliki dampak/nilai positif } \\
\hline & Ya & Tidak \\
\hline & 73 & 27 \\
\hline \multirow[t]{3}{*}{5} & \multicolumn{2}{|c|}{ Apakah anda tahu bahwa minum minuman yang beralkohol dapat merusak kesehatan ? } \\
\hline & $\mathrm{Ya}$ & Tidak \\
\hline & 96 & 4 \\
\hline \multirow[t]{3}{*}{6} & \multicolumn{2}{|c|}{$\begin{array}{l}\text { Apakah anda mengetahui bahwa minum minuman beralkohol dapat berdampak buruk pada } \\
\text { kesehatan kita? }\end{array}$} \\
\hline & $\mathrm{Ya}$ & Tidak \\
\hline & 96 & 4 \\
\hline \multirow[t]{3}{*}{7} & \multicolumn{2}{|c|}{$\begin{array}{l}\text { Setuju anda bahwa jika meminum minuman yang beralkohol dapat mengakibatkan dampak yang } \\
\text { buruk pada kesehatan kita? }\end{array}$} \\
\hline & Setuju & Tidak \\
\hline & 87 & 13 \\
\hline \multirow[t]{3}{*}{8} & \multicolumn{2}{|c|}{ Menurut anda apakah minuman beralkohol seharusnya tidak dikomsumsi berlebihan? } \\
\hline & Setuju & Tidak \\
\hline & 64 & 36 \\
\hline \multirow[t]{3}{*}{9} & \multicolumn{2}{|c|}{ Menurut anda, apakah kebiasaan minum minuman Baram harus dikurangi ? } \\
\hline & Ya & Tidak \\
\hline & 96 & 4 \\
\hline \multirow[t]{3}{*}{10} & \multicolumn{2}{|c|}{ Setujukah anda jika anak muda yang dibawah umur turut mengikuti budaya minum Baram ? } \\
\hline & Setuju & Tidak \\
\hline & 36 & 64 \\
\hline
\end{tabular}


Tabel 3. Persentase Respon masyarakat suku Dayak Katingan terhadap minuman Baram menurut Kultur

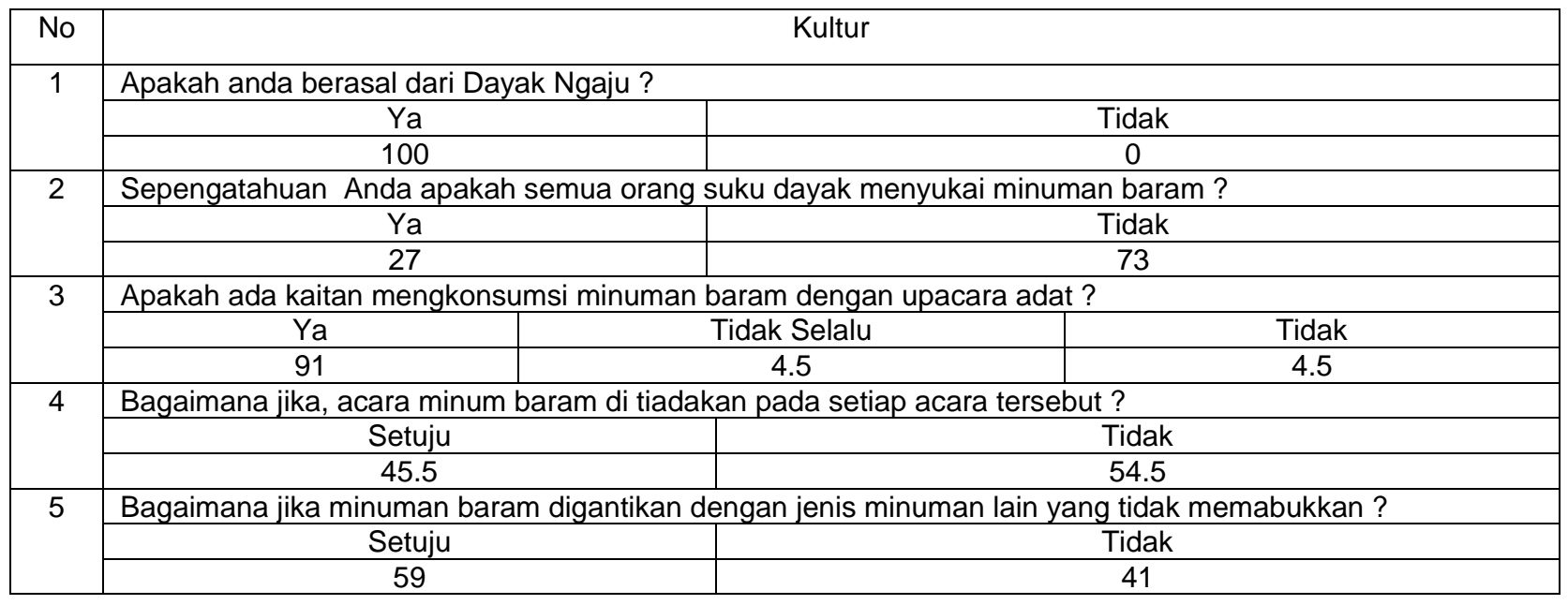

Tabel 4. Hasil uji Laboratorium minuman Baram

\begin{tabular}{|c|c|c|c|c|}
\hline A. & \multicolumn{3}{|c|}{ ORGANOLEPTIK: Berbentuk: cair, agak keruh, warna kekuningan, bau khas dan rasa khas. } \\
\hline B. & Uji kimia/ Fisika & Hasil & Syarat & Metoda/ Pustaka \\
\hline 1. & Kadar Metanol & $0 \%$ & HPST & Kromatografi Gas MAPPOMN 24/ PA/ 05 \\
\hline 2. & Kadar Etanol & $5,6 \%$ & HPST & Kromatografi Gas MAPPOMN 24/ PA/ 05 \\
\hline C. & Uji Mikrobiologi & Hasil & Syarat & Metoda/ Pustaka \\
\hline \multicolumn{5}{|c|}{ KESIMPULAN : HSPT } \\
\hline
\end{tabular}

*sumber : Hasil Uji Balai POM Palangkaraya

Tabel 5. Mikroorganisme yang berperan dalam minuman Baram

\begin{tabular}{|l|c|c|c|}
\hline \multicolumn{1}{|c|}{ Mikroorganisme } & \multicolumn{3}{|c|}{ Lama fermentasi minggu ke- } \\
\cline { 2 - 4 } & 1 & 2 & 3 \\
\hline Saccharomyces cerevisiae dan Saccharomyces bayanus & + & + & + \\
& + & + & + \\
\hline Aspergillius onzae & + & + & - \\
\hline
\end{tabular}

Tabel 6. Uji organoleptik minuman Baram berdasarkan umur pengguna

\begin{tabular}{|c|l|c|c|}
\hline \multicolumn{2}{|c|}{ Uji organoleptik } & Persentase Responden & Umur \\
\hline \multirow{3}{*}{ warna } & Bening & $20 \%$ & $21-25$ \\
\cline { 2 - 4 } & Kecoklatan & $0 \%$ & $26-30$ \\
\cline { 2 - 4 } & Kekuning kuningan & $80 \%$ & $31-35$ \\
\hline \multirow{3}{*}{ aroma } & Tidak menyengat & $30 \%$ & $36-39$ \\
\cline { 2 - 4 } & Kurang menyengat & $70 \%$ & $40-45$ \\
\cline { 2 - 4 } & Menyengat & $0 \%$ & $45-49$ \\
\hline \multirow{3}{*}{ Rasa } & Pahit & $40 \%$ & $50-55$ \\
\cline { 2 - 4 } & Manis & $60 \%$ & $56-59$ \\
\cline { 2 - 4 } & Tawar & $0 \%$ & $60-65$ \\
\hline \multirow{2}{*}{ Kekeruhan } & Cukup keruh & $70 \%$ & $70-75$ \\
\cline { 2 - 4 } & Keruh & $0 \%$ & $76-79$ \\
\cline { 2 - 4 } & Tidak keruh & $30 \%$ & \\
\hline
\end{tabular}




\section{KESIMPULAN DAN SARAN}

Hasil penelitian ini dapat disimpulkan 1) Persepsi masyarakat suku dayak di wilayah Katingan kal-Teng tentang minuman "Baram" menunjukkan sebagian besar masyarakat masih banyak yang belum mengetahui kandungan alkohol pada minuman Baram sehingga terdapat kecenderungan mereka masih selalu menggunakan Baram sebagai minuman pada upacara tertentu karena mereka belum memiliki pemahaman yang baik tentang dmpak positif negatifnya dari minuman Baram 2) Kandungan alkohol yang terdapat pada minuman "Baram" termasuk kategori cukup tinggi yaitu sebesar 5,6 $\%$ etanol, relatif lebih tinggi di bandingkan dengan minuman Tuak sebesar $4 \% 3$ ) Mikroorganisme yang berperan pada proses fermentasi minuman "Baram" adalah Saccharomyces cerevisiae dan Saccharomyces bayanus serta Aspergillius onzae 4) Berdasarkan hasil uji organoleptik terhadap minuman "Baram" pada masyarakat suku Dayak di wilayah Katingan Kalimantan Tengah dapat disimpulkan bahwa masyarakat menyukai minuman baram karena rasa dan aromanya khas

Adapun saran dalam penelitian ini,1) Masih perlu ditindaklanjuti penelitian ini dengan memperluas pertanyaan-pertanyaan dalam kuesioner untuk penggalian informasi yang masih belum terungkap secara rinci dalam penelitian ini, 2) Perlu dilakukan kajian bagi masyarakat pengguna minuman baram untuk dicarikan alternatif jenis minuman pengganti lain yang lebih aman tetapi memiliki rasa menyerupai minuman baram tetapmengandung beralkohol sehingga tidak membahayakan dari segi kesehatan dan tidak memberikan dampak sosial.

\section{DAFTAR PUSTAKA}

Arkanudin. 2001. Perubahan Sosial Peladang Berpindah Dayak Ribun Parindu Sanggau Kalimantan Barat, Bandung: Tesis Program Magister Pascasarjana Universitas Padjadjaran.

James. M. Henslin, 2002. Essential of Sociology: A Down to Earth Approach Fourth Edition. Boston: Allyn and Bacon. HIm 10.

Kamanto Sunarto. 2004. Pengantar Sosiologi. Jakarta: Lembaga Penerbit FE UI. HIm. 5

Soekanto, soerjono, 2010. Sosiologi Suatu Pengantar. Jakarta, Raja Grafindo persada

Sujarni Alloy, Dkk. 2008. Mozaik Dayak Keberagaman Subsuku Dayak di Kalimantan Barat. Jakarta 